\title{
Simulasi Sistem Pendeteksi Objek Pada Pesawat Dengan Menggunakan Teknologi SAR (Synthetic Aperture Radar)
}

\section{( Simulation of Object Detection System in Aircraft Using SAR Technology )}

\author{
M.I. Asysyakuur ${ }^{1 *}$, D.M. Arifin ${ }^{2}$, A.S. Satyawan ${ }^{3}$, N.N.A.M. Santi ${ }^{4}$, N. Nufus ${ }^{5}$, \\ R.A.S. Nugraha ${ }^{6}$, Ema $^{7}$ \\ 1,3,4,5,6, Teknik Elektro, Universitas Nurtanio \\ E-mail: ikromasy.te16@student.unnur.ac.id,marlina.te20@student.unnur.ac.id, \\ nufus.te20@student.unnur.ac.id, radityasn.te16@student.unnur.ac.id, ema@unnur.ac.id \\ ${ }^{2}$ Prodi Teknik Aeronautika Pertahanan, Akademi Angkatan Udara, Yogyakarta \\ E-mail:denden8552@aau.ac.id \\ ${ }^{3}$ Badan Riset dan Inovasi Nasional, Universitas Jambi \\ E-mail: arief.suryadi@akane.waseda.jp
}

\begin{abstract}
To map an object in the form of the contours of an area will be difficult if you use a passive sensor system such as a camera because of its limitations to penetrate clouds, fog, and erratic weather. Therefore, better technology is needed to map an object from above the earth's surface or the air. Synthetic Aperture Radar (SAR) is a mapping technique using radar to produce high-resolution maps of the earth's contours or describe an object and present information in the form of images or images. SAR can work in any weather conditions, whether in the rain, snow, or even fog. Another SAR capability is to be able to detect objects with a fairly good level of accuracy. Based on the above, research and development of SAR technology is very necessary. In this research, preliminary studies on SAR technology have been carried out. This research is intended to complement the capabilities of drones or unmanned aerial vehicles (UAVs) both for imaging the contours of the earth and activities related to society 5.0 so that the application can be used for modern agriculture, forestry, marine, and border observation activities. The goal is to simulate the detection of objects that are on the ground. There are two simulated SAR-based object detection methods, namely Range Migration Algorithm and Back Projection Algorithm. This simulation was built using a computer with an AMD A8 processor, 8 GB of memory, and MATLAB 2019 software. The simulation results show that the system design for both algorithms can work well at a frequency of $4 \mathrm{GHz}$ with a resolution range of $3 \mathrm{~m}$. The image displayed in this simulation is in 2-D form. The average processing time of the two algorithms to be able to detect objects is 103.2 seconds. The image displayed in this simulation is in 2-D format. While the average processing time of the two algorithms to be able to detect objects is 103.2 seconds.
\end{abstract}

Keywords - SAR, Range Migration Algorithm, Back Projection Algorithm, UAV, society 5.0

Abstrak-Untuk memetakan suatu objek berupa kontur suatu daerah akan terasa sulit jika menggunakan sistem sensor pasif seperti kamera karena keterbatasannya untuk menembus awan, kabut dan cuaca yang tidak menentu. Oleh sebab itu diperlukannya teknologi yang lebih baik untuk dapat memetakan suatu objek dari atas permukaan bumi atau udara. Synthetic Aperture Radar (SAR) adalah teknik pemetaan dengan menggunakan radar untuk menghasilkan peta kontur bumi dengan resolusi tinggi, atau menggambarkan suatu objek serta menyajikan informasi dalam bentuk citra atau gambar. SAR dapat bekerja dalam kondisi cuaca apapun, baik dalam keadaan hujan, salju atau bahkan kabut sekalipun. Kemampuan SAR lainnya adalah untuk dapat mendeteksi objek dengan tingkat keakuratan 
yang cukup baik. Beradasarkan hal tersebut di atas, penelitian dan pengembangan teknologi SAR sangat diperlukan. Pada penelitian ini studi awal mengenai teknologi SAR telah dilakukan. Penelitian tersebut dimaksudkan untuk dapat melengkapi kemampuan drone atau unmanned aerial vehicle (UAV) baik untuk pencitraan kontur bumi maupun aktifitas terkait society 5.0. Sehingga aplikasinya dapat digunakan untuk keperluan pertanian modern, kehutanan, kelautan, dan kegiatan pengamatan perbatasan. Tujuannya adalah untuk mensimulasikan pendeteksian objek yang berada di permukaan tanah. Terdapat dua metoda pendeteksian objek berbasis SAR yang disimulasikan, yaitu Range Migration Algoritma dan Back Projection Algoritma. Simulasi ini dibangun dengan menggunakan komputer dengan prosesor AMD A8, memori 8 GB dan softperaware MATLAB 2019. Hasil simulasi memperlihatkan bahwa disain system untuk kedua algoritman tersebut dapat bekerja baik pada frekuensi $4 \mathrm{GHz}$ dengan range resolusi $3 \mathrm{~m}$. Citra yang ditampilkan pada simulasi ini dalam bentuk 2-D. Sedangkan waktu pemrosesan rata-rata dari ke dua algoritma tersebut untuk dapat melakukan pendeteksian objek adalah 103.2 detik.

Kata kunci-SAR, Range Migration Algorithm, Back Projection Algorithm, UAV, society 5.0

\section{Pendahuluan}

$S$ ynthetic Aperture Radar (SAR) adalah teknik pemetaan radar udara untuk menghasilkan peta resolusi tinggi untuk menggambarkan suatu objek atau menyajikan informasi dalam bentuk citra atau gambar. SAR dapat bekerja dalam kondisi dan cuacaapapun, baik hujan, salju bahkan kabut sekalipun. Kemampuan SAR sendiri dapat mendeteksi seperti pergerakan musuh dalam bidang militer, menentukan koordinat letak suatu benteng pertahanan musuh, mendeteksi kondisi cuaca, siang hari ataupun malam hari selain itu SAR juga dapat mendeteksi objek dengan tingkat keakuratan yang cukup baik.

Belakangan ini SAR merupakan suatu piranti yang banyak diminati dan mulai banyak penelitian yang dilakukan dibidangnya, pasalnya SAR selain dapat beroprasi pada semua cuaca SAR juga memiliki keunggulan dari radar lainnya seperti jangkauannya bisa lebih luas dan pengoprasiannya juga dapat jauh lebih efisien di bandingkan radar lainnya. Atas dasar hal tersebut, penulis bermaksud dalam tugas akhir ini menujukan pengaplikasian radar SAR sebagai alat pendeteksian objek disekitar pesawat yang diterapkan dalam interface MATLAB. Proses perencanaan system ini dilakukan dengan menggunakan gelombang sinyal LFM agar dapat mempermudah untuk melakukan screening di udara [1].

\section{LANDASAN TEORI}

\section{A. Synthetic Aperture Radar (SAR)}

Synthetic Aperture Radar (SAR) merupakan suatu jenis modifikasi sistem radar untuk menghasilkan gambar sebagai pengganti tampilan jarak (range) dan arah. SAR adalah sebuah sistem radar yang memanfaatkan teknik pemrosesan sinyal yang mampu menghasilkan pemetaan gambar yang memiliki hasil dengan resolusi tinggi, dengan pengindraan jarak jauh atau diluar batasan antena aperture fisik yang dapat diartikan sebagai suatu antena yang berukuran kecil yang akan memberikan hasil seperti antena yang berukuran lebih besar dengan cara menggerakan antena tersebut. SAR menggunakan sensor aktif, berbeda dengan citra pengindaaran jarak jauh lainnya yang menggunakan sensor pasif, Sensor pasif hanya menerima pantulan balik dari objek dan bergantung pada keberadaan matahari atau sumber panas lainnya, sedangkan sensor aktif mengeluarkan radiasi energinya sendiri untuk mendapatkan pantulan balik dari objek tersebut sehingga memungkinkan untuk menggunakan panjang gelombang yang lebih panjang dengan mencapai resolusi tinggi dua dimensi gambar dari siang hari ataupun malam hari. Dan juga dapat bekerja pada semua kondisi cuaca sehingga memungkinkan untuk menembus awan, karena bekerja pada frekuensi gelombang mikro dan panjang gelombang yang dihasilkan lebih panjang dibandingkan dengan gelombang optik biasanya (visible bands). Pada Gambar 1 menunjukan perbandingan dari sensor pasif dan sensor aktif. 


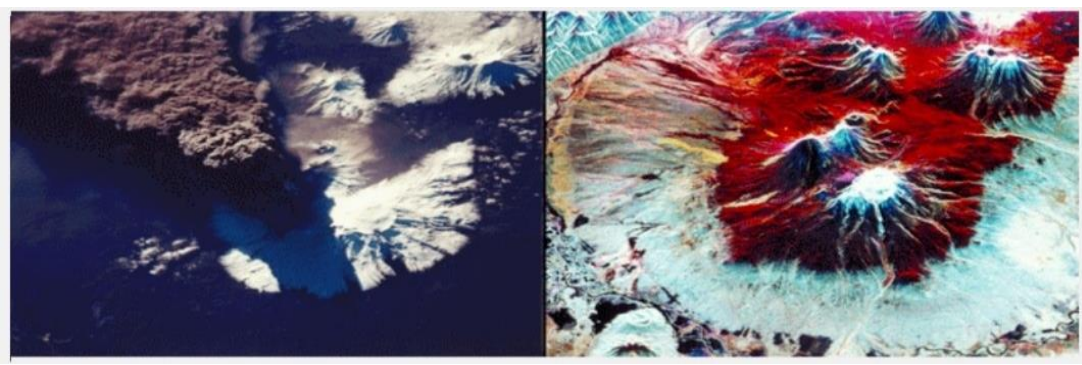

Gambar 1. Perbandingan Sensor Aktif Dan Pasif [2].

\section{Prinsip Dasar SAR}

Konsep radar SAR adalah mengukur jarak dari sensor ke target dengan wahana pesawat terbang atau satelit yang dilakukan ke arah miring (side looking). Ukuran jarak tersebut didapat dengan mengukur waktu yang diperlukan gelombang elektromagnetik selama penjalarannya mulai dari sensor sampai ke target dan kembali lagi ke sensor. Pada Gambar 2 menunjukan prinsip dasar kerja radar [7].

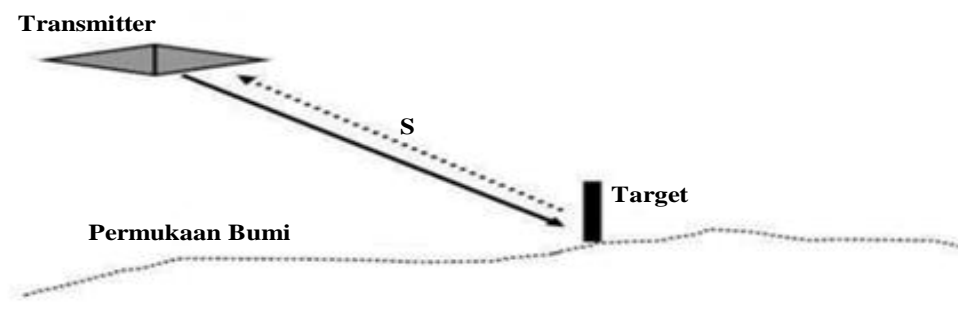

Gambar 2. Prinsip dasar kerja radar [3].

Pengukuran jarak antara radar dengan target dapat dihitung dengan menggunakan persamaan (1).

$$
\mathrm{S}=\frac{\mathrm{c} \Delta \mathrm{t}}{2}
$$

Dimana: $\quad \mathrm{c}=$ Kecepatan cahaya.

$\mathrm{S}=$ Jarak antara antena dengan target di permukaan bumi.

$\Delta \mathrm{t}=$ Waktu tempuh gelombang elektromagnetik

Pada permukaan bumi, pulsa gelombang radar dipancarkan ke segala arah, sebagian pantulannya diterima kembali oleh radar. Intensitas dari gelombang pantulan ini sangat lemah dibandingkan ketika dipancarkan.

Ketika pesawat memancarkan sinyal radar, pantulan sinyal memiliki bentuk geometri tersendiri. Berikut ini adalah faktor-faktor geometri pada pencitraan radar, yaitu:

a. Incidence Angle, Merupakan sudut yang dibentuk antara pancaran gelombang radar dengan garis yang tegak lurus terhadap permukaan objek. Sebagaimana yang disimbolkan $\boldsymbol{\theta}$ pada Gambar 3.

b. Depression Angle, Adalah sudut yang dibentuk dari arah horizontal ke arah garis pancaran gelombang radar. Seperti yang disimbolkan G pada Gambar 3.

c. Look Angle, Merupakan sudut antara utara geografis dan arah pancaran gelombang radar atau dengan garis yang tegak lurus dengan arah terbang pesawat. Seperti yang disimbolkan' $Y$ pada Gambar 3.

d. Look Direction, Merupakan arah antena saat melakukan pencitraan. Arah antena pada radar SAR akan selalu tampak side looking sebagaimana yang ditunjukan pada Gambar 3. 


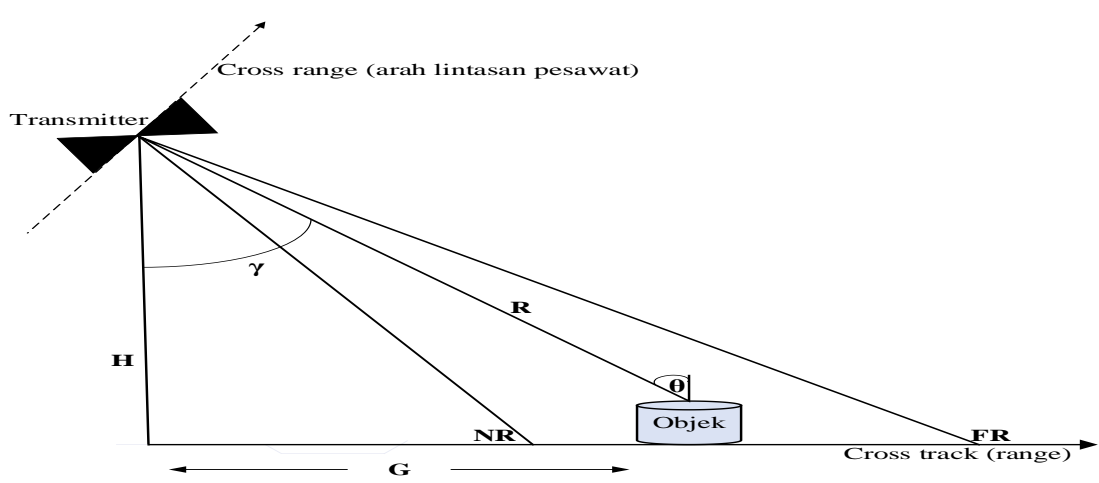

Gambar 3. Geometri Pada Pencitraan Radar [3].

2. Resolusi Radar

Resolusi radar diartikan dengan kemampuan radar untuk memvisualisasikan suatu objek dengan benar yaitu bisa membedakan objek yang letaknya berdekatan. Resolusi radar yang digambarkan pada bentuk sel-sel resolusi pada sistem radar ini tergantung pada dua parameter yaitu panjang pulsa dan lebar sorot antena. Panjang pulsa atau disebut juga durasi pulsa radar ditentukan oleh lamanya antena melepas atau memancarkan gelombang elektromagnetik. Resolusi radar terbagi atas 2 bagian menurut arahnya, yaitu:

a. Resolusi Searah Lintasan (Azimuth Resolution)

b. Resolusi Melintang Lintasan (Range Resolution)

Resolusi Searah Lintasan (Azimuth Resolution) Resolusi pada arah azimuth (ra) merupakan resolusi yang sejajar dengan arah terbang wahana. Dengan kata lain yaitu kemampuan dari radar untuk membedakan objek yang berlainan yang searah lintasan pesawat. Resolusi searah azimuth tergantung pada lebar sorot $(\beta)$ dari gelombang mikro yang dipancarkan dan jarak dari pesawat ke objek. Pada Gambar 4 menunjukan resolusi pada sebuah radar.

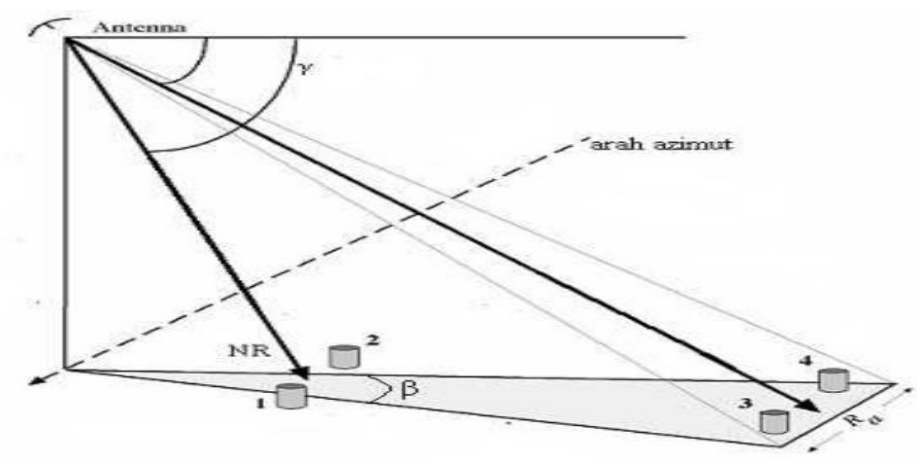

Gambar 4. Azimuth Resolution

Dari Gambar 4 terlihat bahwa semakin besar lebar sorot $(\beta)$ akan mengakibatkan resolusi azimuth yang rendah. Begitu pula semakin jauh objek dari antena maka resolusi azimuth akan semakin besar (resolusinya rendah). Pada Gambar 4, objek 1 dan 2 bisa dipisahkan (tampak sebagai dua objek yang berbeda), namun objek 3 dan 4 tidak bisa dibedakan masing-masing objeknya, sehingga tampak sebagai satu objek [3]. 


\section{B. Back Projection Algorithm}

Back Projection Algorithm (BPA) memiliki dua metode: Time-domain backprojection dan frequency-domain backprojection. Time-domain backprojection memiliki lebih banyak keunggulan dibandingkan frequency-domain backprojecrion dan dengan demikian, lebih disukai. Time-domain backprojection membentuk gambar atau spektrum dengan mencocokkan data yang diperoleh dari radar dan sesuai dengan apa yang diharapkan untuk diterima. Ini dapat dianggap sebagai filter cocok yang ideal untuk radar apertur sintetis. Tidak perlu ada langkah kompensasi gerakan yang berbeda karena kualitas penanganan gerakan/pengambilan sampel yang diterapkan sudah ideal. Ini juga dapat digunakan untuk berbagai geometri pencitraan [4] [6].

\section{Range Migration Algorithm}

Range migration algorithm (RMA) adalah algoritma utama frekuensi yang mana konversi frekuensi diterapkan dikedua sumbu yaitu, sumbu azimuth dan sumbu jangkauan. Teknik yang digunakan RMA untuk memfokuskan gambar didasarkan pada kelanjutan perambatan bawah dari persamaan gelombang dan juga diambil dari migrasi seismik. Pada algoritma ini persamaan gelombang dijalankan mundur bersamaan dengan arah rambat. Fenomena ini terjadi ketika gelombang merambat dari tingkat bawah ke tingkat atas di bawah tanah. Oleh karena itu, panjang busur terus berkurang saat bergerak menuju target, hingga akhirnya busur itu berubah menjadi satu titik. Apa yang telah dilakukan dalam praktik dalam kasus SAR adalah bahwa platform tersebut dianggap berada di permukaan tanah. Jika demikian, maka posisi sinyal pantulan yang diterima akan berada di sepanjang jalur lokasi target. Jadi, dengan kelanjutan pancaran ke bawah dari muka gelombang sepanjang dimensi slant range, gema yang diterima terbaca pada posisi platform [5] [6].

\section{MODEL YANG DIUSULKAN}

\section{A. Arsitektur Model Secara Umum}

Perancangan simulasi pendeteksian objek selanjutnya dijelaskan pada bagian ini, algoritmanya dapat dilihat seperti pada Flowchart dibawah. 


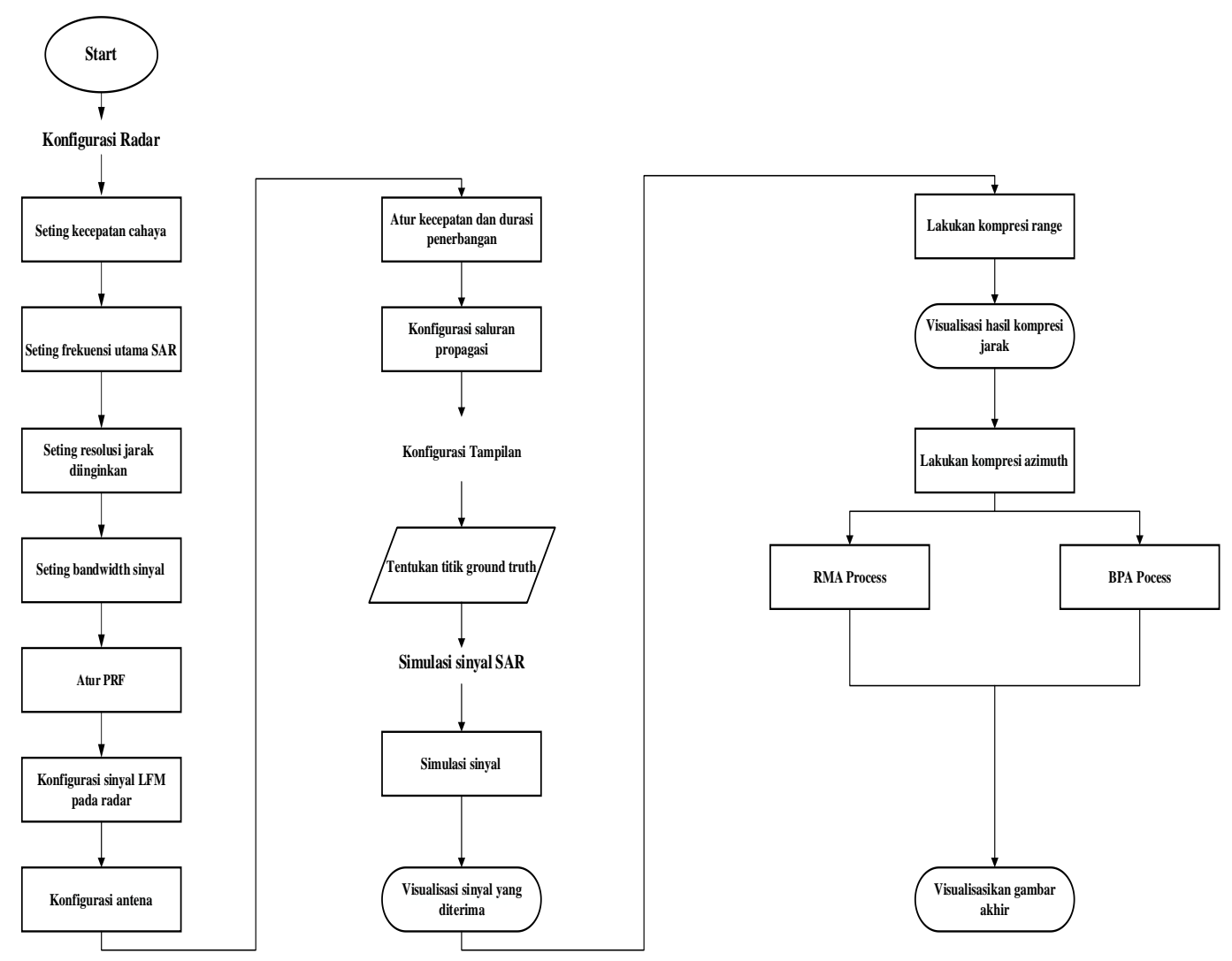

Gambar 5. Flowchart

IV. IMPLEMENTASI MODEL DAN PEMBAHASAN

\section{A. Implementasi Model}

Pada implementasi model ini ground truth ini diasumsikan posisi pesawat terletak pada titik 0 , jadi objek merah berada sejajar dengan posisi antena pada pesawat, objek hijau berada dibelakang pesawat / telah di lalui pesawat dan objek biru berada di depan pesawat / belum dilalui pesawat.

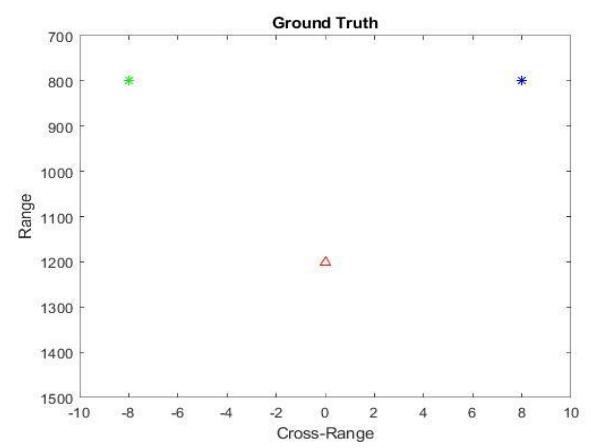

Gambar 6. Ground truth

Prosiding Seminar Nasional Sains Teknologi dan Inovasi Indonesia - Akademi Angkatan Udara

Volume 3, Tahun 2021: hlm. 41-52 


\section{B. Pembahasan}

Pada bab ini akan dijelaskan tahapan pengujian simulasi sistem pendeteksian objek pada pesawat dengan menggunakan teknologi SAR, berdasarkan empat pengujian yaitu frekuensi, range resolusi, far and near range dan waktu pengujian.

\section{Pengujian Dengan Perubahan Frekuensi}

Pada pengujian ini dilakukan perubahan frekuensi pada frekuensi $1 \mathrm{GHz}, 4 \mathrm{GHz}, 6 \mathrm{GHz}$, $7 \mathrm{GHz}$, dengan catatan bandwith yang ada tidak dirubah dan resolusi jarak juga tetap, pengujian ini dilakukan dengan tujuan agar objek yang di deteksi dapat terlihat sama seperti ground truth yang ada. Pada Gambar 6 menunjukan ground truth dari objek yang akan dideteksi.

a. Sinyal yang Diterima

Pada Gambar 7, 8, 9, 10 menunjukan gambar sinyal yang diterima.

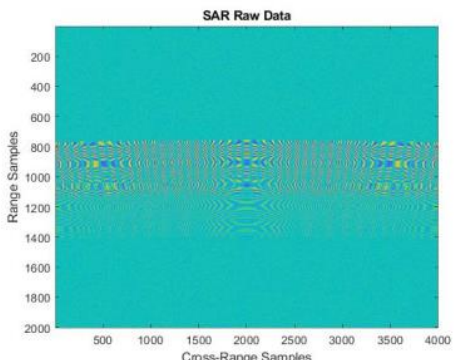

Gambar 7. Sinyal $1 \mathrm{GHz}$

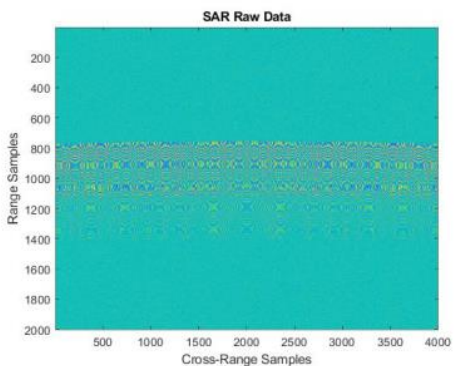

Gambar 9. Sinyal $6 \mathrm{GHz}$

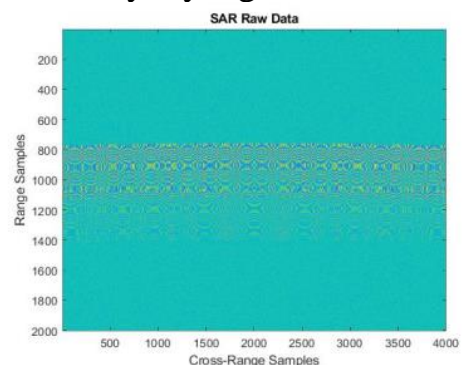

Gambar 8. Sinyal $4 \mathrm{GHz}$

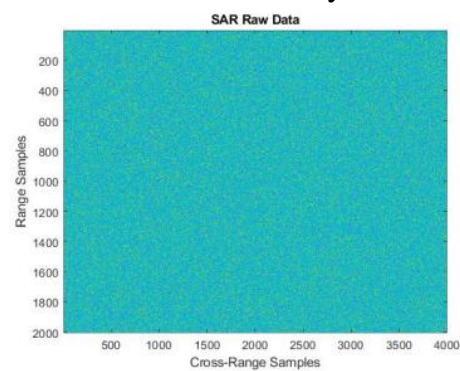

Gambar 10. Sinyal $7 \mathrm{GHz}$

b. Sinyal yang Telah Dikompresi

Sedangkan pada Gambar 11, 12, 13, 14, menunjukan sinyal yang telah dikompresi

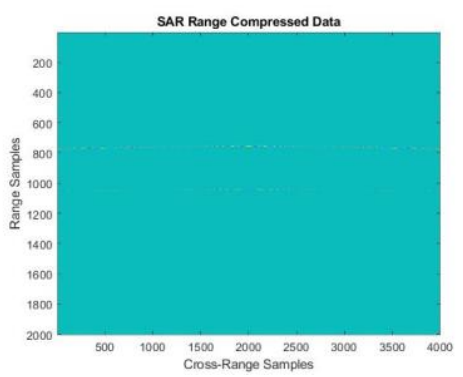

Gambar 11. Sinyal $1 \mathrm{GHz}$

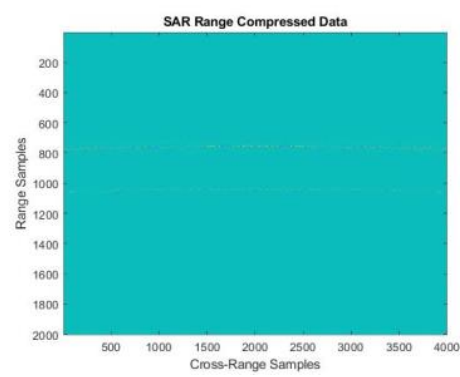

Gambar 12. Sinyal $4 \mathrm{GHz}$ 


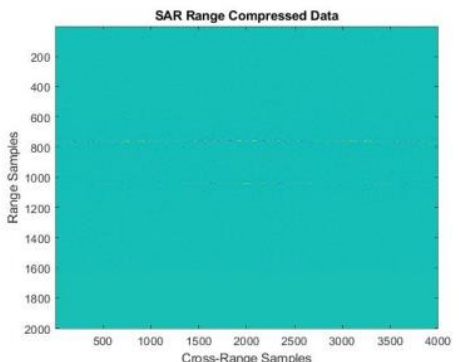

Gambar 13. Sinyal $6 \mathrm{GHz}$

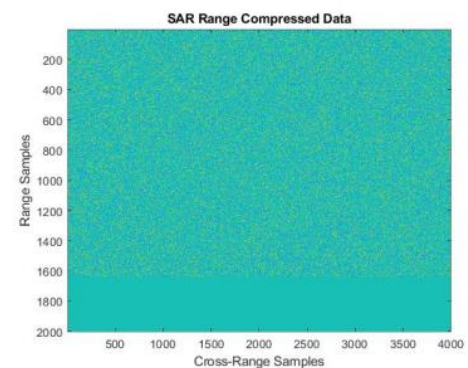

Gambar 14. Sinyal $7 \mathrm{GHz}$

TABEL I

Pengujian 1

\begin{tabular}{|l|c|c|c|c|}
\hline Frekuensi & Sinyal datang & Sinyal Proses & RMA & BPA \\
\hline $1 \mathrm{Ghz}$ & $\checkmark$ & $\checkmark$ & $\checkmark$ & $\mathrm{x}$ \\
\hline $4 \mathrm{Ghz}$ & $\checkmark$ & $\checkmark$ & $\checkmark$ & $\checkmark$ \\
\hline $6 \mathrm{Ghz}$ & $\checkmark$ & $\checkmark$ & $\mathrm{x}$ & $\checkmark$ \\
\hline $7 \mathrm{Ghz}$ & $\mathrm{x}$ & $\mathrm{x}$ & $\mathrm{x}$ & $\mathrm{x}$ \\
\hline \hline
\end{tabular}

Pada pengujian dengan melakukan perubahan frekuensi, didapat hasil sebagai berikut:

1) Pada tampilan sinyal awal, terlihat pada frekuensi $1 \mathrm{GHz}$, sinyal tampak dengan jelas, dan semakin di tinggikan frekuensinya maka semakin tidak jelas sinyal yang di tangkap oleh radar terlihat pada Gambar sinyal $7 \mathrm{GHz}$ sinyal sudah tidak tampak, yang artinya sinyal sinyal tidak tertangkap oleh radar.

2) Setelah melakukan pemfilteran pada sinyal yang ada, terlihat tampilan pada Gambar 11 terdapat 2 garis sinyal, yang mewakili 3 objek yang di proyeksikan, objek 1 dan objek 3 terletak sejajar searah dengan azimuth (cross range), sehingga tampak seperti hanya 1 sinyal, objek 2 tidak sejajar dengan objek lainnya sehingga sinyalnya tampak berbeda dengan yang lainnya. Oleh karena itu sinyal yang tampil hanya terlihat seperti 2 sinyal.

2. Pengujian Dengan Perubahan Resolusi Jarak (Range Ressolution)

Pada pengujian ini berterkaitan pada rumus bandwith, yang mana bila ada perubahan para range resolution maka otomatis akan terjadi perubahan pula pada bandwidth, tetapi Frekuensi yang di gunakan tetap. Pengujian yang di lakukan yaitu pada renge ressolition $1 \mathrm{~m}, 3 \mathrm{~m}, 5 \mathrm{~m}$, dan $7 \mathrm{~m}$. Pada tahap pengujian ini ground truth yang di gunakan masih sama seperti pada Gambar 6 .

a. Hasil Tampilan Range Mitigration Algorithm (RMA)

Pada Gambar 15, 16, 17, 18 menampilkan hasil pencitraan pengujian ke-2 dengan menggunakan algoritma RMA.

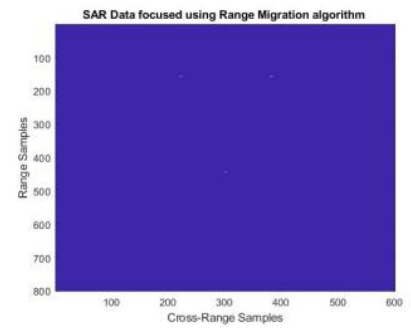

Gambar 15. Tampilan RMA $1 \mathrm{~m}$

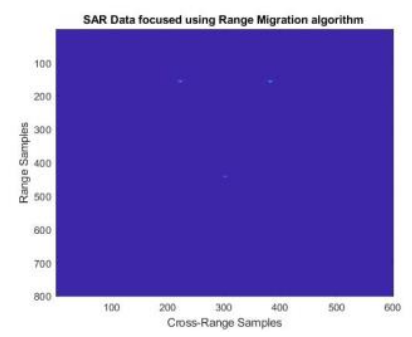

Gambar 16. Tampilan RMA 3 m

Prosiding Seminar Nasional Sains Teknologi dan Inovasi Indonesia - Akademi Angkatan Udara

Volume 3, Tahun 2021: hlm. 41-52 


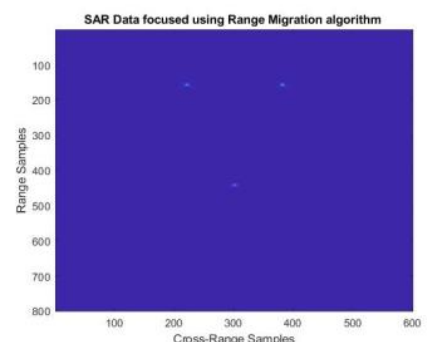

Gambar 17. Tampilan RMA 5 m

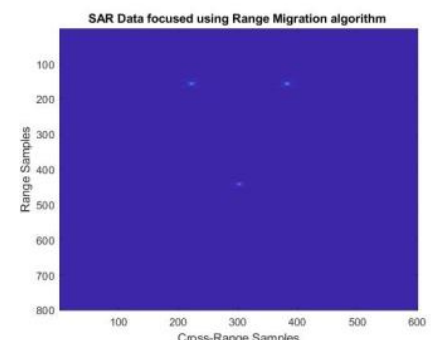

Gambar 18. Tampilan RMA 7 m

b. Hasil Tampilan Back Projection Algorithm (BPA)

Sedangkan pada Gambar 19, 20, 21, 22 menampilkan hasil pencitraan pengujian ke 2 dengan menggunakan algoritma BPA.

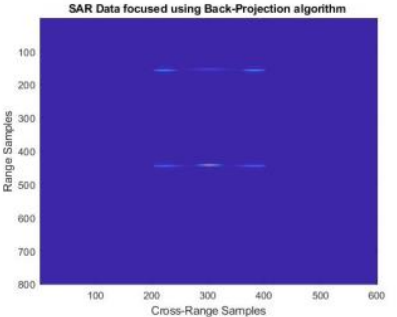

Gambar 19. Tampilan BPA $1 \mathrm{~m}$

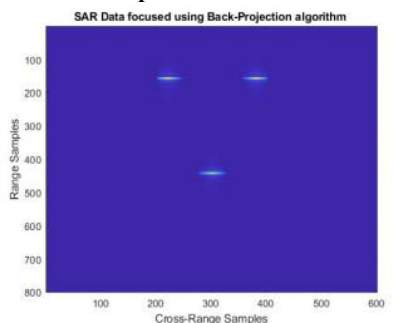

Gambar 21. Tampilan BPA $5 \mathrm{~m}$

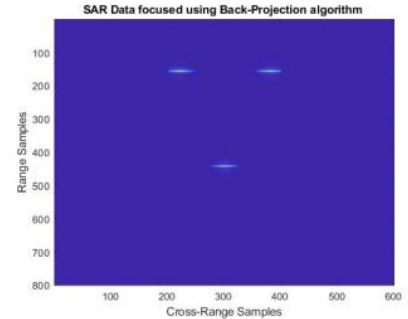

Gambar 20. Tampilan BPA $3 \mathrm{~m}$

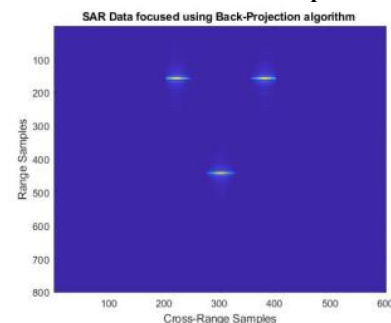

Gambar 22. Tampilan BPA $7 \mathrm{~m}$

Pada Tabel II menunjukan hasil dari pengujian range ressolution yang telah dilakukan dengan menggunakan rr $1 \mathrm{~m}, 3 \mathrm{~m}, 5 \mathrm{~m}, 7 \mathrm{~m}$.

TABEL II

Pengujian 2

\begin{tabular}{|c|c|c|}
\hline \hline RR & RMA & BPA \\
\hline $1 \mathrm{~m}$ & $\checkmark$ & $\mathrm{x}$ \\
\hline $3 \mathrm{~m}$ & $\checkmark$ & $\checkmark$ \\
\hline $5 \mathrm{~m}$ & $\checkmark$ & $\mathrm{x}$ \\
\hline $7 \mathrm{~m}$ & $\checkmark$ & $\mathrm{x}$ \\
\hline
\end{tabular}
berikut:

Pada pengujian dengan melakukan perubahan range resolution, didapat hasil sebagai

a. Pada tampilan RMA, terlihat pada rr 1m terlihat sudah tampak, tetapi resolusi yang dihasilkan masih sangat kecil atau kurang jelas, ketika dinaikan ke rr 3m resolusinya sudah lebih baik dan tampil titik yang merupakan proyeksi dari ground truth yang dibuat, pada range resolusi $5 \mathrm{~m}$ dan $7 \mathrm{~m}$ resolusi juga sudah cukup baik dan titik sesuai dengan yang di proyeksikan oleh ground truth.

b. Pada hasil tampilan akhir menggunakan Back Projection Algorithm (BPA), dengan menggunakan rr $1 \mathrm{~m}$ terlihat pada gambar 19 objek yang diproyeksikan tidak menyerupai ground truth, kemudian di naikan $\operatorname{rr} 3 \mathrm{~m}$ dan hasil yang diproyeksikan lebih Simulasi Sistem Pendeteksi Objek Pada pesawat Dengan menggunakan Teknologi SAR (Synthetic Aperture Radar) (Mohammed Ikrom Asysyakuur) 
baik gambar menyerupai ground truth dan resolusi yang dihasilkan terlihat jelas, kemudian terlihat pada rr 5 dan $7 \mathrm{~m}$, resolusi tampak terlalu berlebihan sehingga terlihat seperti ada noise pada gambar yang diproyeksikan.

\section{Pengujian Far and Near Range}

Setiap radar memiliki batasan jangkauan terjauh dan terdekat pada pengindraanya, pada pengujian ini dibuat 6 sample ground truth, dimana setiap ground truth ditujukan untuk menguji jarak terjauh dan terdekat yang dapat dicapai oleh radar dengan ketentuan frekuensi yang digunakan $4 \mathrm{GHz}$, bandwidth $50 \mathrm{MHz}$ dan range resolution $3 \mathrm{~m}$, bentuk pengujian ini dengan cara membuat ground truth sejajar dengan antenna kemudian mengubah ubah ground truth secara kontinyu, mendekat dan menjauh dari arah antenna, hingga objek yang ada tidak dideteksi oleh radar.

\section{a. Ground Truth}

Pada Gambar 23, 24, 25, 26, 27, 28, menunjukan ground truth dengan jarak objek yang berbeda-beda, sehingga didapat hasil dari far and near range yang akan dicari pada pengujian ini.

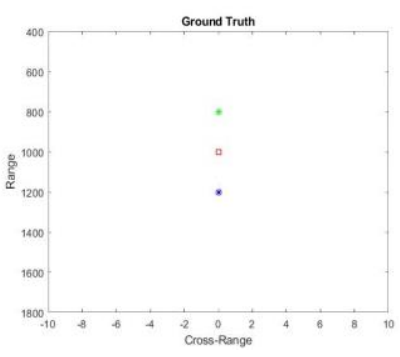

Gambar 23. Ground truth 1

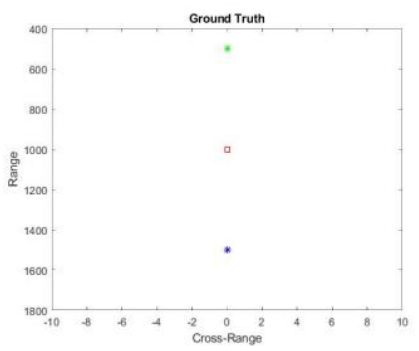

Gambar 26. Ground truth 4

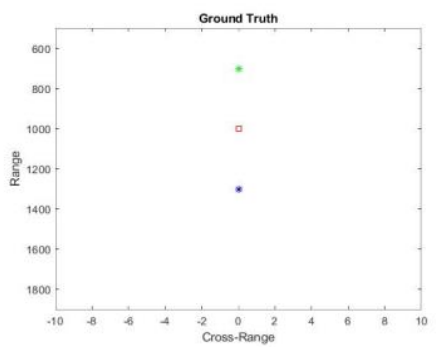

Gambar 24. Ground truth 2

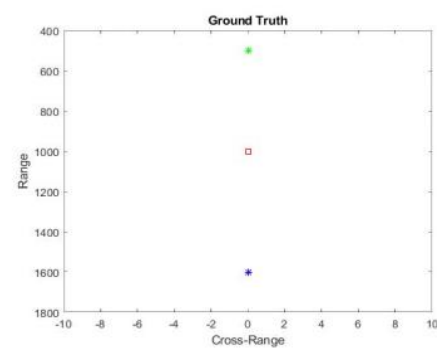

Gambar 27. Ground truth 5

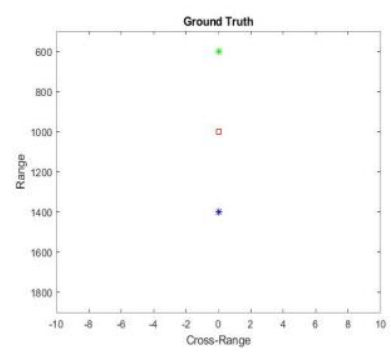

Gambar 25. Ground truth 3

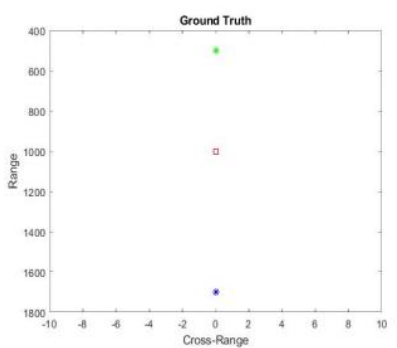

Gambar 28. Ground truth 6

\section{b. Hasil Tampilan RMA}

Pada Gambar 29, 30, 31, 32, 33, 34, menampilkan hasil pencitraan pengujian ke-3 dengan menggunakan algoritma RMA.

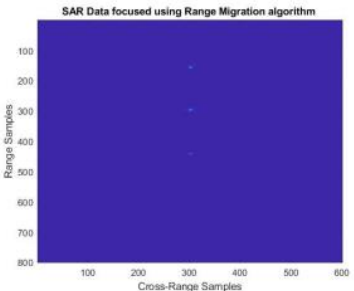

Gambar 29. Tampilan RMA 1

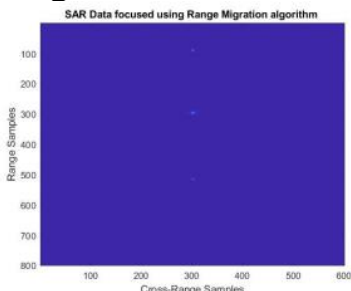

Gambar 30. Tampilan RMA 2

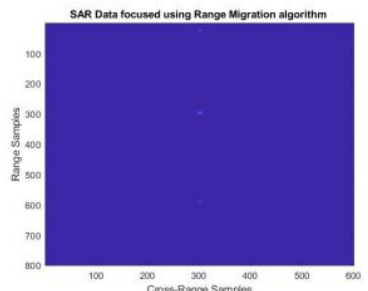

Gambar 31. Tampilan RMA 3

Prosiding Seminar Nasional Sains Teknologi dan Inovasi Indonesia - Akademi Angkatan Udara

Volume 3, Tahun 2021: hlm. 41-52 


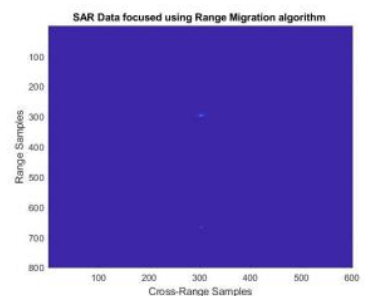

Gambar 32. Tampilan RMA 4

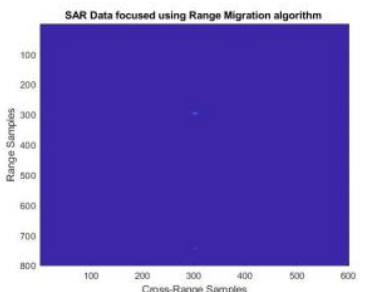

Gambar 33. Tampilan RMA 5

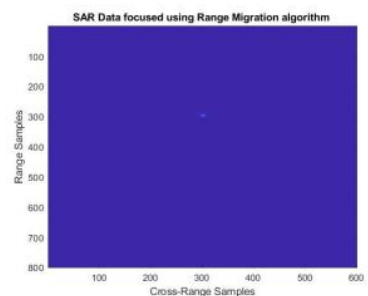

Gambar 34. Tampilan RMA 6

c. Hasil Tampilan BPA

Sedangkan pada Gambar 35, 36, 37, 38, 39, 40, menampilkan hasil pencitraan pengujian ke-3 dengan menggunakan algoritma BPA.

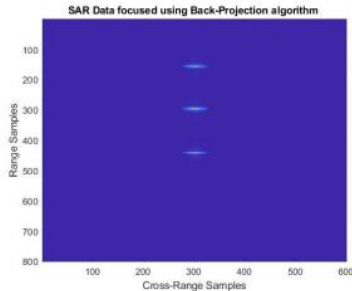

Gambar 35. Tampilan BPA 1

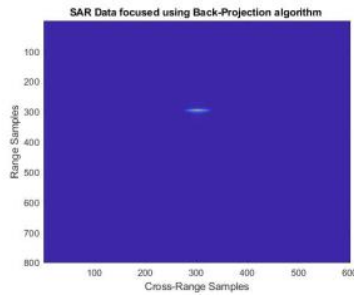

Gambar 38. Tampilan BPA 4

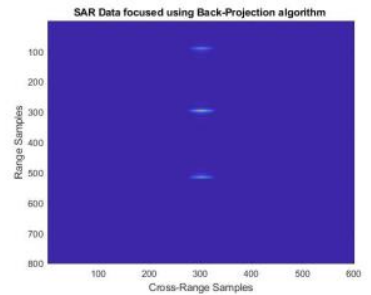

Gambar 36. Tampilan BPA 2

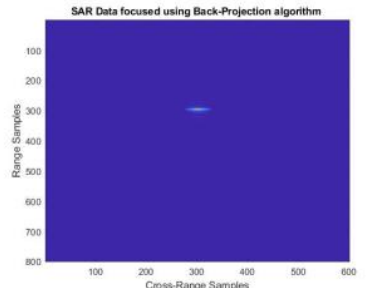

Gambar 39. Tampilan BPA 5

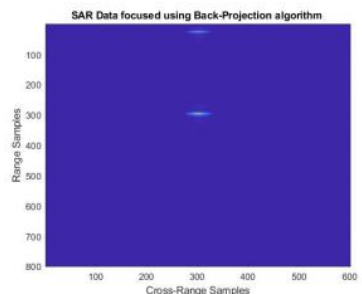

Gambar 37. Tampilan BPA 3

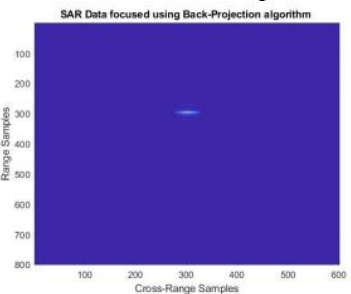

Gambar40. Tampilan BPA 6

Pada pengujian far and near range ini, didapat hasil analisa sebagai berikut:

a. Pada pengujian ini menggunakan tampilan RMA, didapat far range yang masih bisa ditangkap oleh radar yaitu dikisaran 1600, terlihat pada Gambar 31, ketika dinaikan pada jarak 1700 objek sudah tidak terlihat sama sekali. Adapun untuk near range atau jarak terdekat yang bisa ditangkap oleh radar yaitu pada kisaran 600, terlihat pada Gambar 33 objek masih terlihat, dan ketika didekatkan pada jarak 500 objek sudah out of range atau tidak terdeteksi seperti yang ditampilkan pada Gambar 34.

b. Pada hasil tampilan akhir menggunakan BPA, didapat far range yang masih bisa di tangkap oleh radar yaitu di kisaran 1300, terlihat pada Gambar 37, ketika dinaikan pada jarak 1400 objek sudah tidak terlihat sama sekali seperti yang ditampilkan pada Gambar 38. Adapun untuk near range atau jarak terdekat yang bisa ditangkap oleh radar yaitu pada kisaran 600, terlihat pada Gambar 36 objek masih terlihat, dan ketika didekatkan pada jarak 500 objek sudah out of range atau tidak terdeteksi seperti yang ditampilkan pada Gambar 37.

4.Pengujian waktu pemrosesan sinyal

Pada pengujian ini dilakukan perekaman waktu pada setiap pemrosesan sinyal, dimana pemrosesan menggunakan computer 1 dengan spesifikasi sebagai berikut.
a. RAM
: $8 \mathrm{~GB}$
b. Operating System
: Windows 10 Pro 64-bit
c. Processor
: AMD A8-7410 2.2 GHz
d. Graphic
: AMD Radeon R-5 Graphic 
Dari 5 perekaman waktu yang dilakukan, didapat hasil rata-rata waktu pemrosesan selama 103.2 detik. Sedangkan dengan menggunakan computer 2 dengan spesifikasi
a. RAM
: 32 GB
b. Oprating system
: Windows 10 Pro 64-bit
c. Processor
: Intel core i9-990k $3.6 \mathrm{GHz}$
d. Graphic
: NVIDIA GeForce RTX 3080

Dari jumlah perekaman waktu yang sama didapat hasil rata-rata waktu pemrosesan selama 16.0 detik. Ini menunjukan untuk mendapatkan performa yang maksimal dalam memproses sinyal SAR memerlukan teknologi prosesor yang sangat baik.

\section{KESIMPULAN}

Dari uraian diatas dapat disimpulkan bahwa pembuatan simulasi sistem pendeteksi objek pada pesawat dengan menggunakan teknologi SAR telah berhasil dibuat dan berfungsi dengan baik dalam jangkauan terbatas, simulasi ini dilakukan pada MATLAB dengan menggunakan algoritma BPA dan RMA.

Untuk pengembangan lebih lanjut dapat dilakukan dengan memperluas jangkauan sehingga dapat diaplikasikan pada pesawat yang sesungguhnya dan juga bisa menggunakan tampilan SAR 3D, sehingga objek yang dideteksi dapat terlihat lebih real, pengembangan ini bisa dilakukan pada MATLAB.

\section{UCAPAN TERIMA KASIH}

Ucapan terima kasih kami sampaikan kepada pihak pihak yang telah berkontribusi dalam penelitian ini hingga makalah ini dapat di publikasikan pada Seminar Nasional Sains Teknologi dan Inovasi Indonesia 2021, diantaranya kepada:

a. LPDP (Lembaga Pengelola Dana Pendidikan) sebagai sponsor penelitian.

b. BRIN (Badan Riset dan Inovasi Nasional) sebagai penyedia prasarana penelitian.

c. Universitas Nurtanio sebagai penyedia prasarana penelitian.

d. AAU (Akademi Angkatan Udara) sebagai perguruan tinggi kerjasama dengan Yasau untuk kolaborator penulisan naskah dan penyiapan konferensi serta prosiding.

e. Serta rekan rekan - rekan peneliti lainnya.

\section{REFERENSI}

[1] Cumming, I., Bennett, J., 1979. Digital Processing of Seasat SAR data. IEEE International Conference on Acoustics, Speech, and Signal Pro-cessing

[2] "Pengenalan terhadap Synthetic Aperture Radar (SAR)" https://sryhandiniputeri.medium.com/pengenalanterhadap-synthetic-aperture-radar-sar-538bc0e59189.

[3] Haniah, Yudo Prasetyo.. Pengenalan teknologi radar untuk pemetaan spasial di Kawasan tropis, Vol. 32 No.2 Tahun 2011, ISSN 0852-1697

[4] Yegulalp, A.F., 1999. Fast backprojection algorithm for synthetic aperture radar. Proceedings of the 1999 IEEE Radar Conference.

[5] Na Y., Lu Y., Sun H.,A., 2006. Comparison of Back-Projection and Range Migration Algorithms for UltraWideband SAR Imaging, Fourth IEEE Workshop on Sensor Array and Multichannel Processing, Waltham, MA, 2006, pp. 320-324.

[6] Cafforio, C., Prati, C. and Rocca, F., 1991. SAR data focusing using seis-mic migration techniques. IEEE transactions on aerospace and electronic systems, 27(2), pp.194-207

[7] "Pengertian matlab dan fungsi bagian-bagiannya" http://febriani1998.blogspot.com/2016/12/pengertian-matlabdan-fungsi-bagian.html 